\title{
Emergence of corporate political activities in the guise of CSR: dispatches from a developing economy
}

DOI:

10.1108/AAAJ-07-2019-4087

\section{Document Version}

Accepted author manuscript

Link to publication record in Manchester Research Explorer

\section{Citation for published version (APA):}

Siddiqui, J., Mehjabeen, M., \& Stapleton, P. (2021). Emergence of corporate political activities in the guise of CSR: dispatches from a developing economy. Accounting, Auditing and Accountability Journal, 34(5), 1137-1162. https://doi.org/10.1108/AAAJ-07-2019-4087

\section{Published in:}

Accounting, Auditing and Accountability Journal

\section{Citing this paper}

Please note that where the full-text provided on Manchester Research Explorer is the Author Accepted Manuscript or Proof version this may differ from the final Published version. If citing, it is advised that you check and use the publisher's definitive version.

\section{General rights}

Copyright and moral rights for the publications made accessible in the Research Explorer are retained by the authors and/or other copyright owners and it is a condition of accessing publications that users recognise and abide by the legal requirements associated with these rights.

\section{Takedown policy}

If you believe that this document breaches copyright please refer to the University of Manchester's Takedown Procedures [http://man.ac.uk/04Y6Bo] or contact uml.scholarlycommunications@manchester.ac.uk providing relevant details, so we can investigate your claim.

\section{OPEN ACCESS}




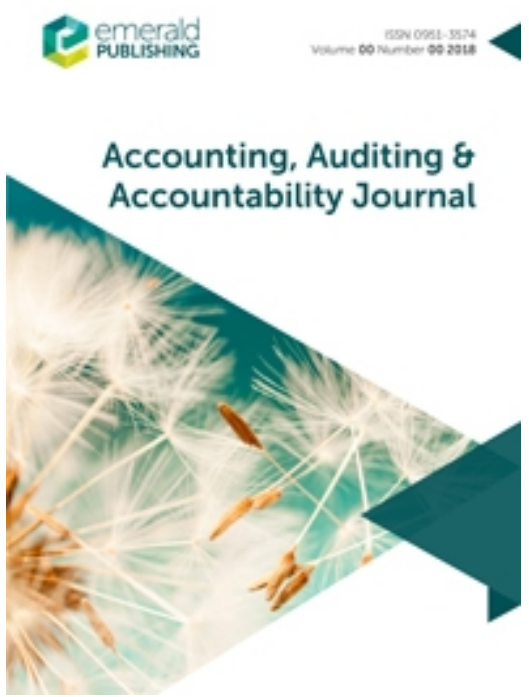

\section{Emergence of corporate political activities in the guise of CSR: dispatches from a developing economy}

\begin{tabular}{|r|l|}
\hline Journal: & Accounting, Auditing \& Accountability Journal \\
\hline Manuscript ID & AAAJ-07-2019-4087.R3 \\
\hline Manuscript Type: & Research Paper \\
\hline Keywords: & $\begin{array}{l}\text { Social and environental reporting, Institutional logics, Corporate political } \\
\text { activity, Corporate social reporting }\end{array}$ \\
\hline \multicolumn{2}{|l}{} \\
\hline
\end{tabular}

\section{SCHOLARONE ${ }^{m}$ \\ Manuscripts}




\section{EMERGENCE OF CORPORATE POLITICAL ACTIVITIES IN THE GUISE OF CSR: DISPATCHES FROM A DEVELOPING ECONOMY}

\section{Introduction}

The objective of this paper is to explore the emergence of corporate political activities (CPA) in Bangladesh. As in many other developing countries, the corporate sector in Bangladesh is characterized by highly concentrated family ownership (Khan et al, 2015). The capital market is weak; investors possess limited knowledge regarding investment decisions (Siddiqui, 2010). In this context, existing literature reports a lack of market incentive to engage in corporate social reporting (CSR) (Siddiqui, 2010; Muttakin et al, 2018), and so CSR disclosures in Bangladeshi companies tend to be inadequate and unreliable (Belal, 2001; Belal and Owen, 2007; Khan et.al, 2013; Momin and Parker, 2013).

However, since 2009, there has been a significant increase in CSR disclosures by banks in Bangladesh (Bangladesh Bank, 2010). Closer scrutiny shows there may be varying reasons behind this activity. For example, some activities reported by commercial banks can be traced to political projects closely linked to the ruling political party and its family members (Uddin et al, 2018). Using Weber's (1947) notion of traditionalism, Uddin et al. (2018) conclude that such activities are aimed at demonstrating unconditional loyalty to the state political leadership. Their paper also reports that many commercial banks in Bangladesh have significant political linkage through family owners. Similarly, a number of studies (for example, Siddiqui and Uddin, 2016; Siddiqui et al, 2020) also report the presence of a state-business nexus in Bangladesh, where businessmen occupy the majority of seats in parliament. Furthermore, media reports present evidence that family-owners of commercial banks exert significant influence on the government, and have policies formed in their favour (The Daily Star, 2017). Thus, contrary to Uddin et al, (2018), it is possible that the political nature of CSR activities of Bangladeshi banks may also be driven by a desire to get close to the political leadership with an intention to maximise their own political or economic agenda, rather than simply displaying loyalty to political masters. On the other hand, there is evidence that some activities appear to be undertaken purely for the benefit of society. For example, the various activities engaged in by commercial banks during natural disasters (The New Age, 2020). Thus overall, there is sufficient anecdotal evidence to suggest there are a variety of reasons for commercial banks 
engaging in CSR activities of a political nature. In this context, the paper addresses the following question: how did CPA emerge in the form of CSR in the banking sector in Bangladesh?

In order to address the contextual factors that influence a company's choices to engage with CSR activities, our paper is grounded in the notion of institutional logics (Friedland and Alford, 1991), a key feature of which is the acknowledgement of a logical pluralism, where different logics coexist within an organization. That is, faced with the prospect of having to adopt a new instituional practice, an organization may align the logics of those new practices with the existing logics of the organization. Indeed, prior literature investigating structural embeddedness of CSR programmes within organizations have suggested that such adoption is influenced by the presence of multiple logics within the organizations (Glynn and Raffaelli, 2013; Arena et al, 2018). An institutional logics perspective (Thornton and Ocasio, 2011; Maguire et al, 2004) also allows the identification of certain mechanisms through which a new logic may replace the existing dominant logic within an organization, hence making it a useful theoretical lens to investigate a change in existing institutional logics within organizations.

Although there has been rising interest in the political aspects of CSR in the general management literature (Schrere and Palazzo, 2007. 2011; Whelan, 2012; Fynas and Stephens, 2015; Muthuri and Gilbert, 2011; Chapple and Moon, 2007; Prechel and Morris, 2010; Walker and Rea, 2014; Lux et al, 2011), accounting researchers have paid relatively scant attention to this important contextual factor. Consequently, the dynamics between politics and CSR disclosures have remained relatively under researched (Gu et al, 2013) and undertheorized (Uddin et al, 2018). Exceptions include several studies in the market-based accounting literature that have studied the impact of CPA on corporate performance (Bonardi, et al, 2006; Hillman et al, 1999). However, as noted by Adly (2009), the absence of complete institutions in developing countries can drive political engagement by corporations. Also, unlike western countries, where CPA is largely legal, such activities are not legally permissible in many developing countries. Therefore, it is possible that corporations in developing countries may attempt to camouflage CPA in the form of other legitimate activities, such as CSR. Our paper aims to contribute to this small but growing literature on CPA in the context of developing countries. 
Our analysis is based on 21 in-depth interviews with top management and members of the board of directors across the Bangladeshi banking industry as well as policymakers and regulatory bodies. Our findings reveal that the Bangladeshi corporate sector's approach towards engagement with and disclosure of CSR activities is driven by the existence of multiple logics across different industries. We find the political nature of the CSR activities performed by banks in Bangladesh is primarily dictated by the presence of a dominant market logic within the industry. However, in some cases, such activities are influenced by the existence of multiple logics, such as family and community. Our analysis makes an important contribution to the accounting literature: our study is amongst the first to explore the emergence of CPA, and the role of institutional entrepreneurs in the context of a developing economy. Also, by adopting institutional logics as a theoretical lens for this research, we extend previous studies such as Uddin et al. (2018) and Khan et al. (2020) to demonstrate that the political nature of CSR disclosures made by banks in Bangladesh is shaped by the presence of multiple logics within organizations.

The paper is divided into several sections. Section 2 provides a brief literature review of the political nature of CSR reporting. This is followed by a section that elaborates the theoretical framework adopted for this study. A following section then discusses the research methods employed. The empirics are presented in two successive sections followed by a discussion section. Finally, the conclusion section summarizes the findings and provides future research directions.

\section{Corporate political activity (CPA) versus corporate political social responsibility (PCSR)}

Corporations can engage in a variety of political activities, including building businessgovernment relationships, corruption, contributions, and overt lobbying (Baysinger, 1984). In return, firms can benefit from reduced transaction costs and reduced environmental uncertainty (Hillman et al, 1999). They may also be able to manage or influence public policy in their favour (Baines and Viney, 2010). In the context of this research, Lawton et al. (2013) notes that the nature of CPA might be different in developing and western countries. In the western context, CPA is largely about firm-level legal engagement with structured political actors, 
whereas in developing economies the presence of weak or incomplete institutionalization can lead to informal and possibly corrupt political engagement by corporations (Adly, 2009).

Frynas and Stephens (2015) emphasize the importance of integrating corporate political and CSR literatures because both address corporate interaction with political institutions, nongovernment actors, and local communities. These authors define political CSR (PCSR) as activities where CSR has 'an intended or unintended political impact or where intended or unintended political impacts on CSR exist' (p. 485). Borrowing from Lawton et al.'s (2013) depiction of CPA, Frynas and Stephens (2015) argue that corporate attempts to influence governmental policies could include: deliberate attempts by corporations to influence governments to gain firm-specific advantage; the impacts of firms' reactive strategies with regard to changes in the external political environment; and identifying deliberate corporate strategies in response to environmental concerns, with the aim of influencing future government regulation (Halme, 2002; Ruihua and Bansal, 2003). However, some activities such as lobbying government for assistance in international trade disputes (Baron, 1997) were excluded from Frynas and Stephens' definition because they are not explicitly related to CSR.

Although both PCSR and PCA are concerned with corporate engagement with political activities, the two concepts are clearly distinguished. As Scherer et al. (2016) point out, businesses not only engage with political activities, sometimes they turn into political institutions themselves. That is, for these authors the political understanding of CSR goes beyond the instrumental view of corporate engagement with politics, as expressed in the CPA literature, where CPA is defined as corporate attempts to shape government policies in a way that is favourable to the firm (Hillman and Hilt, 1999). Such attempts may include activities such as campaigning contributions, direct lobbying, co-option, or even bribing. Thus, CPA literature takes a very instrumental view of the term 'politics', meaning political activities of the state. Here, corporations make no attempt to fill any governance vacuum left by the state apparatus. Rather, the intention is to exploit state activities for the corporations' own benefit. This definition of politics is more akin to our interpretation of the term for the purpose of this research. The notion of politics as used in PCSR literature, on the other hand, focuses on deliberations, collective actions, and a concern for public goods (Scherer et al, 2014). Thus, PCSR is viewed as an attempt by corporations to close governance gaps at national, regional and global levels. 
The prevalence of political interests and patronage in corporations is well noted in the wider management literature (Chapple and Moon, 2007; Lux et. al, 2011; Muthuri and Gilbert, 2011; Walker and Rea, 2014; Maak et. al, 2016). However, this work mainly addresses the political duties and activities of, in particular, multinational corporations (MNCs) (Crane et al, 2008; Hsieh, 2009; Scherer and Palazzo, 2007, 2011). Within the normative tradition of research, researchers find that western MNCs play positive roles in societies (Scherer et. al, 2006, 2009), and even that MNCs may step up to fulfill that role as increased globalization leads to a decline in the power of the state (Whelan, 2012). There are not many critical studies conducted on politically motivated CSR except for Whelan (2012), Gu et al. (2013) and Siddiqui et al (2020). Whelan (2012) criticizes prior research by arguing it is wrong to equate globalization with diminishing capacities of states and by questioning whether MNCs are capable of oscillating between rational profit-seeking and pro social logics.

Although Uddin et al. (2018) refer to the political nature of CSR activities of Bangladeshi banks as 'political CSR', the nature of such activities indicate that these are more akin to CPA rather than PCSR. In fact, Uddin et al. (2018) use Skippari's (2005) typology of CPA to explore the nature of political activities performed by banks in Bangladesh, where, as the authors note, corporations are not legally allowed to provide election funding to political parties. Based on an analysis of CSR disclosures made in their annual reports, the paper finds that a significant number of CSR activities can be classified as CPA, mostly due to personal connections between business executives and politicians. Using Weber's notions of traditionalism, the paper concludes that such activities were used as mechanisms for displaying loyalty to the 'master' (p. 409), as warranted in a traditional economy. Within the market-based accounting literature, there is evidence that CPA is positively related to firm performance (Bonardi et. al, 2006; Hillman et al, 1999). Cooper et al. (2010) observe that donating to a political party helps corporations develop close relationship with politicians, which can have a positive impact on stock prices if the politicians get elected to office. In Bangladesh's case, Uddin et al. (2018) suggest there may not be any direct benefit derived by the corporation from engaging in such political activity, although, the family owners might benefit. This paper views willing participation in CSR activities that actively promote the ruling party's political agenda as an effort to display loyalty. However, at the same time, media reports present significant evidence of how family-owners of commercial banks in Bangladesh, exert significant influence on the government, and have policies formed in their favour (The Daily Star, 2018). This is possible due to the presence of a significant state-business nexus, as reported in many other studies (for 
example, Siddiqui and Uddin, 2016; Siddiqui et. al, 2020). As the Bangladeshi legal environment does not allow firms to directly contribute towards election funding of political parties, it is possible that such CPA is conducted in the guise of CSR.

But by way of contrast, there is also evidence that commercial banks engage in various activities that appear to be truly beneficial for society (The New Age, 2020). Thus, it appears that the significant increase in CSR activities in the banking sector in Bangladesh, and the political nature of such practices is an outcome of the presence of multiple factors. In such a context, institutional logics (Thornton et al, 2012) may be a useful lens through which to study emerging organizational practices and practice variations (Ezzamel et al, 2012; Malik and Nicholson, 2020). Especially, attention may be focused on the existence of logical pluralism within organizations. For example, studies have examined how a particular logic is prioritized over others under different circumstances (Safari et al, 2020; Golyagina, 2020; Yee, 2020). In what follows, we elaborate on institutional logics and logical pluralism, especially in the context of CSR research.

\section{Institutional logics, institutional entrepreneurs, and logical pluralism in CSR research}

The theoretical framing for this paper is based on the notion of institutional logics, conceptualized by Friedland and Alford (1991). Institutional logics have been defined as 'the socially constructed, historical patterns of material practices, assumptions, values, beliefs, and rules by which individuals produce and reproduce their material subsistence, organize time and space, and provide meaning to their social reality' (Thornton and Ocasio 1999, p. 804). Friedland and Alford (1991) identify a number of core institutions of society, namely, the capitalist market, the bureaucratic state, democracy, families, and religion. Each of these institutions has a central logic that dictates the means and ends of individual and organizational behaviour. Building on Friedland and Alford's (1991) work, Thornton and Ocasio (1999) developed a theoretical model to identify six 'ideal type' institutional orders, namely, family, religion, state, market, profession and corporation, each of which has a central logic. The theoretical model compares these six institutional orders across a number of factors, including sources of legitimacy, authority, identity, and basis of attention. A further logical variant, namely community logic, was later introduced by Thornton et al. (2012). 
Friedland and Alford (1991) point out that while institutions constrain actions, they also provide sources of agency and change. Logics are embedded into the fabric of regulatory structures, organizational forms and social norms. Therefore, the contradictions inherent in the different institutional logics provide individuals, groups, and organizations with cultural resources for transforming individual identities, organizations, and society. Thornton and Ocasio (2012) note that change in institutional logics within the organization is facilitated by a number of mechanisms, such as the presence of institutional entrepreneurs, structural overlap, event sequencing, and the presence of multiple logics. These change mechanisms are very relevant for this study, as we explore the emergence of a new practice. For the purpose of this paper, we focus on two of these mechanisms, namely, institutional entrepreneurship, and multiple logics as these seem most relevant in the context of the current study.

The term 'institutional entrepreneurship' was first introduced by DiMaggio (1988) to highlight the change agents within institutions. Institutional entrepreneurship refers to 'the activities of actors who have interest in particular institutional arrangements and who leverage resources to create new institutions or transform existing ones' (Maguire et al, 2004). The notion of institutional entrepreneurship focuses attention on the manner by which interested actors influence their institutional contexts (Lawrence, 1999), and highlights that some people are better at producing desired outcomes than others (DiMaggio, 1998). Garud and Karnoe (2001) note that to qualify as institutional entrepreneurs, individuals must have the ability to break with existing rules and practices associated with the dominant institutional logic and institutionalise the alternative rules, practices and logics they are proposing. Therefore, institutional entrepreneurship is an intense political process that requires skilled actors who can draw on existing cultural and linguistic materials in order to theorize change that would attract the cooperation of other actors (Greenwood et al, 2002; Suddaby and Greenwood, 2005).

Maguire et al. (2004) point out that in the absence of clearly established rules in emerging fields (such as CSR activities in Bangladeshi Banks), institutional entrepreneurs occupying legitimate subject positions, particularly formal, senior positions within organizations, have greater potential to pursue their interests. The formal bureaucratic position of an institutional entrepreneur within the organization would allow them access to material resources that can be diverted to pursue new practices. Also, due to the wide legitimacy of the subject position, the institutional entrepreneur would be equally acceptable, for example, to the top management and the employees within an organization, allowing this entrepreneur to bridge the diverse 
stakeholder groups. Maguire et al. (2004) also highlighted the role of theorization in the institutional entrepreneurship process. Two distinct strategies were identified: persuasive argumentation and political negotiation. The process of persuasive argumentation involves collating a range of arguments that could effectively be used to justify the introduction of new practices in a way that would resonate with various stakeholder groups to create broad based support. Political negotiation includes explicit bargaining, negotiations and compromise with stakeholders to ensure that they are supportive, or at least, do not undermine the proposed changes. Maguire et al. (2004) observes that at this stage, institutional entrepreneurs make clear to stakeholders the political costs of supporting or not supporting the new practices' (p. 671).

Dunn and Jones (2010) note that a number of scholars (for example, Scott et al, 2000) have conceptualised change as a replacement, whereby a dominant logic is abandoned and is replaced by another. Thornton and Ocasio (2012) point out that that the presence of alternative logics per se is not a driver for institutional change. Rather, logical plurality may be an antecedent or a consequence of change. Indeed, over the last decade, a number of studies have reported the existence of logical pluralism within organizations (Amans et al, 2015; Canning and O'Dwyer, 2016; Carlsson-Wall et al, 2017; Ezzamel et al, 2012), for example, in the budgeting process (Ezzamel et al, 2012; Amans et al, 2015). Carlsson-Wall et al. (2017) report the presence of various competing logics in an international Swedish football club, where the organization must manage both a demand for excellence in sport (the sports logic), and a demand for financial success or stability (the business logic). Also, in a recent paper, Siddiqui et al. (2019) report that the shifting nature of global governance reforms in cricket regulatory bodies have been driven by the presence of competing logics, such as imperialism, market logics and professionalism.

Of especial relevance to this paper, a number of studies have adopted the institutional lens to understand how CSR strategies are shaped by the presence of multiple institutional logics within the organization (Arena et al, 2018; Iannou and Serrafaim, 2015; Tan and Wang, 2010). Within CSR literature, Glynn and Rafaelli (2013) note that organizational adoption of CSR practices has been guided by the prevalence of two logics: market and community. Arena et al. (2018) note that the market logic assumes managers will likely prioritize economic results over environmental and social results in the face of multiple demands, and that companies are guided by 'the business case for CSR' when defining their CSR strategies (p. 347). Hence, organizations' responses to social and environmental challenges are instrumental and are 
framed around how firms can benefit financially from addressing societal concerns (Carroll and Shabana, 2010; Gao and Bansal, 2013). Within a market logic, corporate engagement with CSR activities is driven by a pursuit for enhanced legitimacy (Oliver 1990) and reputation management (Bebbington et al., 2008). The community logic-based approach to CSR, on the other hand, focuses completely on the contribution of the company to the community it interacts with and influences (Arena et al, 2018). Within this logic, organizations are viewed as more than economic actors because they are members of local, geographically bounded collectives that order activities by ideologies and value systems. Glynn and Rafaelli (2013) note that CSR practices can be based on either type of logic, but organizations will differ in the extent to which they emphasize the rationale for or benefits of CSR practices. In line with the market logic, market-based practices will emphasize the business benefits. Community-based practices, on the other hand, will emphasize the social benefits that can accrue to organizations from CSR activities. In a recent paper, Mahmood and Uddin (2020) adopt the institutional logics perspective to understand the reasons for the presence of and variation in sustainability reporting in the context of Pakistan. The study confirms that emergence of sustainability reporting practices were underpinned by a combination of market, regulatory, professional and community responsibility logics.

For the purpose of this paper, we use institutional logics to identify the underlying reasons for the sudden emergence of CPA in the banking in industry in Bangladesh. We explore how different institutional logics shape an organization's approach towards CSR. Given the important role of institutional entrepreneurs in changing the existing logic within their organizations, we expect these actors to articulate their logic in order to produce their desired outcomes. The political patronage prevalent in the banking sector also provides an interesting perspective for the logics prevailing in this sector. These issues are elaborated in the research methods section.

\section{Research Methods}

\subsection{The research site: political patronage in the banking sector in Bangladesh}

In 2020, 60 commercial banks operated in Bangladesh, of which 42 were local private commercial banks (PCBs), 9 foreign commercial banks (FCBs) and 9 state-owned banks 
(SOBs). For a relatively small economy like Bangladesh, the number of PCBs is quite high compared to neighbouring economies. For example, India, a much larger economy, has only 22 PCBs and Pakistan just 34 PCBs. Economists and members of civil society in Bangladesh have repeatedly raised concerns regarding the government's tendency to allow new banks to operate (The Dhaka Tribune, 2018). As Uddin et al. (2018) point out, one of the striking features of the banking sector in Bangladesh is the explicit political linkage of the PCBs. Their paper reports that 23 of the 39 PCBs (at the time of the study) had some kind of connection with the ruling regime or other political parties because their chairmen, sponsor directors, or other influential directors of the board were members of parliament or active members of a political party. In 2018, when three more PCBs were given licenses to operate, the finance minister admitted that permission was granted on 'political grounds' despite the banking sector already being overcrowded (New Age, 2018).

The presence of political patronage and linkage has been repeatedly linked with the existence of significant amounts of non-performing loans (NPL) in the banking sector in Bangladesh (ADB, 2019). In 2019, the banking sector had a NPL ratio of $9.89 \%$ - the second highest in Asia (The World Bank, 2019). Although a majority of these NPLs occurred in SOBs, the PCBs also had a significant share of such bad loans (The Financial Express, 2020). In a newspaper interview, a prominent economist in Bangladesh explained that the significant amount of NPLs was due to repeated violation of banks' credit policies and:

'The influence of politicians has helped them to establish new banks without extensive scrutiny and obtain huge amounts of loans ' (Professor Wahiduddin Mahmud, as reported in The Dhaka Tribune, 2018a)

There is evidence of the influence of banks' political linkage in top-level government policy making. In 2018, the Bangladesh Government (GoB) amended the Banking Companies Act (GoB, 2018) to allow four members of the same family to sit on a bank's board of directors, and to hold their posts for nine consecutive year. Previously, the legislations allowed just two members of the same family to be on the board for six consecutive years. Newspaper reports suggest that the Bangladesh Association of Bankers (BAB), the apex body of PCBs in Bangladesh, actively lobbied the government for this amendment (The Dhaka Tribune, 2018b). Also, in 2015 and 2019, the GoB offered a 'generous' restructuring scheme to large bank loan defaulters, allowing them to obtain further loans and other financial benefits from the banks. 
Newspaper reports suggested the presence of political lobbying by bank owners and defaulters (The Daily Star, 2015; 2019a)

There is evidence of political influence in the development of CSR regulations in the banking sector as well. The Bangladesh Companies Act (GoB, 1994) does not require mandatory disclosure of CSR activities for public limited companies. However, in 2008, during the regime of a military-backed, 'caretaker' government led by an ex-World Bank executive ${ }^{1}$, the Bangladesh Bank (BB) issued a circular relating to the mainstreaming of CSR activities in banking and the financial services sector (Bangladesh Bank, 2008), and offered a $10 \%$ tax rebate on the actual amount spent on CSR activities (GoB, 2008). The circular identified specific economic, environmental and social development qualifying activities leading to a threefold reported increase in CSR spending by listed banks in Bangladesh ${ }^{2}$ between 2009 and 2010 (Mehjabeen, 2018). Uddin et al. (2018) note that these expenditures are essentially of a political nature, as they were aimed at glorifying the family of the Prime Minister and were mentioned in the new government's pre-election manifesto. In 2011, the GoB issued a new directive (GoB, 2011), adding donations to the liberation war museum, to the Father of the Nation memorial and contributions to the Prime Minister's Education Fund as new areas of CSR activities that would qualify for tax rebates. The inclusion of political items in the list of CSR activities that could qualify for tax exemption could be viewed as a potential invitation for the Bangladeshi corporate sector to get involved in CPA.

\subsection{Data collection}

This research employs semi-structured interviews with the Governor and ex-governors of the central bank, and members and former members of the Board of Directors of commercial banks, allowing participants to articulate their organizations' approach to CSR reporting practices. The interviews were also intended to understand if there was political interference, which in turn influenced the decision by managers to disclose CSR information. Interviews were also conducted with senior government officials and policymakers including an ex-

\footnotetext{
${ }^{1}$ During 2007-2009, Bangladesh was ruled by a military-backed caretaker government comprised mostly of members of civil society

2 In Bangladesh, Company Law does not require companies to disclose annual CSR expenditure. However, in 2009, the Central Bank of Bangladesh started publishing an annual review of CSR expenditure by banks in Bangladesh. The first of these reports came out in 2010.
} 
finance minister, critics and civil society, the CSR Centre, and the corporate governance wing of International Financial Corporation (IFC), a sister concern of the World Bank.

Initially, a pilot study involving a total of 7 interviews was undertaken to test whether the questions in the interview protocol could result in responses of pertinence to the research objectives (King, 1994; Yeo et al, 2014). The translated and transcribed pilot interviews were used to modify the scope of the initial interview guide/protocol, and to revise the questions addressed in the formal interviews. A total of nineteen interviews (listed in table 1 with codes to ensure anonymity) were conducted between July-September 2015, with additional interviews conducted in April-May 2016 and in July 2019. A further two interviews were conducted in July 2020 via an online platform.

$<$ Table 1 about here $>$

Interviews lasted between 30 minutes and one-and-half hours and took place at the interviewees' place of business. Interviews comprised both basic and probe questions (King and Horrocks, 2010; Roulston, 2010; Shank, 2002) to elicit further explanations, examples, and more detail (Kvale and Brinkmann, 2009; Silverman and Marvasti, 2008; Simons, 2009). Interviews were generally conducted by one of the authors, who is a native speaker, in Bengali (the native language of Bangladesh). All interviews were tape recorded, except two where the interviewees did not agree to tape recording. In these two cases notes were taken with the consent of interviewees. The taped interviews were transcribed, translated and reviewed. Following the method reported by O'Dwyer (2004), recorded interviews were listened to directly and the translation and transcription were carefully scrutinized against the tape recordings and amendments made where necessary.

\subsection{Data analysis}

All interview transcripts and the notes from the two interviews that were not recorded were examined several times to form a deeper understanding of the issues and to focus on one of the relevant aspects. As discussed in the theoretical framework section, in recent times, a number of authors have examined the existence of logical pluralism in the structural embeddedness of CSR practices within organizations (Glynn and Rafaelli, 2013; Arena et al, 2018). In order to understand how different institutional orders influence the CSR practices in organizations, this 
paper employs the notion of ideal types identified by Thornton (2004). Within the CSR literature, Arena et al. (2018) builds on Thornton's (2004) work to provide manifestation of ideal types for CSR strategies. However, for the purpose of our research, we modify Arena et al.'s (2018) framework. Whereas Arena et al. (2018) identify the ideal types for four institutional orders, namely, market, community, state and profession, for the purpose of this paper, we use two of these institutional orders, namely, market and community, given the emphasis of these two orders in CSR practices in organizations (Glynn and Rafaelli, 2013), as well as our reading of the interviews. Instead, considering the emphasis placed by Uddin et al.'s (2018) study on the impact of traditionalism on CSR practices in Bangladesh, we add the ideal types for the order of family for our analysis. The ideal type of CSR strategy for family is identified by combining Thonrton's (2004) framing with Kim and Chung's (2017) work on the ideal types for family governance in Taiwan.

\section{$<$ Table 2 around here $>$}

Table 2 presents the ideal types of CSR strategy for three institutional orders, namely, market, community and family that we believe to have a significant impact in CSR activities in banks in Bangladesh. As intended by Thornton (2004), the identification of such ideal types provides us with a systematic tool to interpret the cultural meanings of the empirical data. In addition, we use Maguire et al.'s (2004) work to investigate the role of institutional entrepreneurs in installing a new institutional practice in the form of CSR activities. We found the notions of subject position, persuasive argumentation, and political negotiation to be useful in analyzing the role of institutional entrepreneurs in the context of CSR practices in the banking sector.

Although Uddin et al. (2018) attribute the political nature the CSR activities and disclosures by Bangladeshi banks to traditionalism only, our analysis of the interviews suggests the presence of logical pluralism in their approach to CSR. Especially, our analysis suggests that although the BB's approach towards CSR regulations was primarily driven by the logic of community, the PCB's response was driven by the presence of multiple logics of market, family, and community. These are now discussed in the following sections.

\section{Bangladesh Bank's approach towards CSR regulations: driven by the logic of community}


Most interview participants from the banking industry identified the Bangladesh Bank (2008) circular as the main impetus for the sudden rise in CSR expenditure in the banking sector. When asked about the motivations for issuing the order, an ex-Governor of the BB, who was in charge when the circular was issued, said the presence of a military-backed government made it easier for the central bank to push forward with these reforms:

'If I remember correctly, at that time, there was a lot of noise regarding Bangladesh's participation in the UN's (United Nation's) climate finance programmes- there were different donor agencies interested in introducing regulatory changes to introduce sustainable financing-the policy was developed in-house, possibly through the assistance of external consultants' (SUA, Former Governor, Bangladesh Bank)

The Finance Minister from the same military-backed government also cited pressures exerted by international donor agencies for the introduction of tax relief for CSR expenditure. However, initially there was a maximum cap for such CSR expenditure, which was later removed by the political government. With hindsight, the respondent thought that the move was potentially counterproductive, as corporations appeared to use CSR as a 'bribe' (MAI, former Finance Advisor (minister) to the caretaker government, 2007-2009).

Interviews with top management personnel in Bangladeshi PCBs suggest that the real impetus for CSR activities came in 2009, when the new government appointed DAR (a pseudo-name), a prominent University Professor known for his socialist views, to the position of Governor of Bangladesh Bank. As an economist, DAR engaged in first-hand research to find the causes of and the means to remedy poverty (The Financial Express, 2009) ${ }^{3}$. On many occasions, he publicly referred to his modest background, and emphasized the need to help others-

My life has been blessed with the support of the common people. At one time, I went door to door in my village asking for their help. The villagers collected donations for me in a bazaar (local market), allowing me to pay my school tuition fees. Later on in life, I was able to open a school and a college in my area. Whenever I can, with whatever I can, I help whoever needs my help, however, that 150 Taka that was collected for me in the bazaar - I still haven't been able to repay that debt. And if I spent my entire life towards it, I still won't be able to repay that debt (The Daily Sun, 2015).

\footnotetext{
${ }^{3}$ https://web.archive.org/web/20090906012307/http://www.thefinancialexpress-bd.com/2009/04/30/65249.html
} 
DAR's belief appears to be consistent with the logic of community, introduced by Thornton et al. (2012) as a new institutional order. These authors observed that local community had a significant impact on organizational behavior in a variety of instances. For example, in their study on cooperative associations, Scheinberg et al. (2008) report that promises by members of a community to cover each-other's losses helped the financially insecure and vulnerable social groups to be economically independent. According to the community logic, institutions would be defined by a common boundary of shared commitment to community values and ideology and derive their legitimacy through 'belief in trust and reciprocity' (Thornton et al, 2012, p. 73). During the interview, DAR repeatedly emphasized this need for reciprocity:

\begin{abstract}
Bangladesh used to be a feudal society- the Jaminders (landlords) used to collect rent, but they also made schools or hospitals in the local community. The neo-tycoons of Bangladesh are not generous. They are getting all sorts of support from the society. Banks survive on other's deposits. This is coming from the society. So, the banks should be doing something for the society. (DAR, Former Governor, BB)
\end{abstract}

This is consistent with Arena et al.'s (2018) depiction of ideal types for the order of community, that focus on CSR engagement with local actors and collaborative activities in the community. The ex-governor also went on to cite a number of examples where family-controlled banks and other large corporate houses engaged in various CSR related activities following his encouragement:

Even in family-controlled firms, if they have the right motivations, they can do it. They can care about the society (DAR, Former Governor, BB).

It is interesting to note that although DAR was not a member of the ruling political party, he is widely believed to be a keen sympathizer, having written several books on the party and its leaders ${ }^{4}$. When questioned about the political nature of CSR by commercial banks, as identified by Uddin et al. (2018), he frankly admitted that he instructed the banks to do so, as he believed these were good projects. In fact, even loss-making banks were asked to donate money for these projects:

\footnotetext{
${ }^{4}$ Although an economist, DAR published two books on Sheikh Mujibur Rahman', the father of the Prime Minister, titled 'Bangladesh's liberation war and the role of Sheikh Mujibur Rahman', and 'Bangabandhu Shohojpath). A detailed list of DAR's non-academic publications is available here: http://www.usshamunnaybd.org/books-authored-by-dr-DAR-rahman/
} 
Sometimes, we involved the banks in Big Ticket CSR. For example, for the Liberation War Museum project (a political project named in the ruling party's election manifesto), we involved the banks to raise Taka 300 million-all banks participated. Even if the banks did not make profit, we encouraged them to contribute to the Liberation War Musuem project. Today, they don't have profit, but they will have. That is a very good project (DAR, Former Governor, BB).

An ex-Governor of the central bank, who worked with DAR, also mentioned his instrumental role in including political projects in the extended list of CSR activities qualifying for a tax rebate, as issued by the Bangladesh government in 2011:

As far as I can recall, the Governor issued a circular so that the Liberation War Museum can raise money from the commercial banks. We made it easier (AMK, former deputy-governor, $B B$ ).

Overall, DAR appeared to be well-positioned to play the role of institutional entrepreneur. As the governor of the central bank, he held a bureaucratic subject position, having access to political and regulatory resources to support his self-interest (Maguire et al, 2004). Thornton and Ocasio (2007) observe that institutional entrepreneurs apply various mechanisms, including rhetorical strategies (Suddaby and Greenwood, 2005) to manipulate material and symbolic resources. Maguire et al. (2004) also highlight the importance of an institutional entrepreneur to engage in persuasive argumentation, as well as political negotiation. DAR mentioned having repeated discussions regarding the importance of mainstreaming CSR with bank owners at different events. However, he admitted that he was able to get the message across quickly as he had the 'blessing of the political leadership'. Also, he emphasized the need for persuasion, because imposing CSR regulations would have had a counterproductive impact:

As senior regulators, we can motivate others. Regulators can play a role, particularly in the regulatory meeting, they can. However, I do not want to force them- this is why we are only issuing softer regulations in the form of guidance notes (DAR, Former Governor, BB).

As Governor of BB between 2009-2016, DAR actively promoted CSR activities in the banking sector through several quasi-regulatory initiatives in a bid to institutionalize the new practice (Maguire et al, 2004). In 2014, the BB issued commercial banks with guidance about CSR expenditure allocation (Bangladesh Bank, 2014). The guidelines require commercial banks to spend at least $2.5 \%$ of their net profit on CSR activities, and dictate exactly how CSR should be allocated across various sectors. The move was described as part of the 'Bangladesh Bank 
Governor's (DAR) efforts since 2009 to get financial institutions to contribute to the wider society that they operate in' (The Daily Star, 2014). DAR also introduced a Bangladesh Bank annual publication summarizing the CSR initiatives of each commercial bank, hence making the banks more accountable in line with the order of the community (Arena et al, 2018).

\section{The political nature of CSR activities: existence of logical pluralism in the banking sector}

The interview evidence presented above suggests that although DAR had some inclination towards a political party and was willing to use his position to encourage banks to contribute to the ruling party's political agenda, he was originally driven by the community logic that banks should give something back to society. However, as reported by Uddin et al. (2018), many of these post-2009 CSR engagements in the banking sector can be classified as CPA. In what follows, we explore the motivations for PCBs in Bangladesh to engage in CSR activities post-2009 and investigate the reasons for the emergence of political CSR. We use the notion of ideal types, as mentioned in section 4, to identify the existence of institutional logics driving PCBs' engagement with CSR activities. Our analysis reveals that the PCBs approach towards CSR was driven by the existence of multiple logics of market, family, and community.

\subsection{The market logic for the rise of CPA}

Although DAR's initiative to mainstream CSR activities in banks appeared to be driven by his own personal ethos towards community development, interviews with bank officials suggest that such a community logic did not essentially transpire within the industry. Rather, a number of respondents suggested that the PCBs were worried about the consequences of not following the governor's advice. A senior executive of a PCB admitted that in Bangladesh's context, the 'steer' of the BB governor was sufficient for the PCBs to engage in any activities as instructed;

'You have to understand that the consequences of not following the governor's advice in Bangladesh's context. Every single bank has governance and operational weaknesses, and being in the bad books of the governor may result in further scrutiny from the Bangladesh Bank' (DKB, CFO of a commercial bank)

This was echoed by a former governor of the BB who was succeeded by DAR: 
Every organization has some weaknesses; to minimize the threat they give in according to the government pressure. Again, they think that since we are doing good things, let's get close to the power and be visible so that they get additional benefits (SUA, former Governor, BB)

A respondent also pointed out that in hierarchical Bangladeshi society guidance from the governor is presumed to be an 'order'. This respondent identified the lack of consultation as a prime reason for the banks' failure to engage with the community logic:

I do not recall any consultation (before the Bangladesh Bank 2014 guidelines). I know that the Governor was interested in community development and wanted the banks to participate. However, if there were some communications, we could have suggested ways of such engagement. Rather, we received this circular from the central bank that from now on, we have to spend $2.5 \%$ on CSR' (DKB, CFO, commercial bank)

This is consistent with Maguire et al.'s (2004) depiction of 'political negotiation', where the institutional entrepreneur, in an effort to introduce new institutional practices, warns the stakeholders of the consequences of non-compliance, although in Bangladesh's context, DAR did not literally need to spell out such costs.

Interviews with multiple respondents from commercial banks revealed that these banks had limited ownership of DAR's vision based on a community logic. Rather, they strategically used the Bangladesh Bank guidelines (2014) to engage in CSR activities that were consistent with their own prevailing institutional logics. We identified a number of items in the annual reports of banks that could be identified as CPA. For example, several banks made CSR disclosures regarding a one off donation to the 'Lakho Konthe Sonar Bangla' -a state-sponsored worldrecord attempt for the highest number of people singing the national anthem together in a single venue (The Daily Star 2014a). A number of respondents confirmed that banks used the opportunity to donate to the project to demonstrate their loyalty to the Prime Minister (PM) by publishing pictures of the chief executives handing over cheques to the PM for this purpose ${ }^{5}$ :

“The huge money spent by big companies to government's programs for patronage. For example, National Anthem song, 'Lakho Konthe gaan'. All companies jumped off to give money to celebrate this, as this would give us the chance to demonstrate to the market that we are close to the ruling regime." (ExAD1)

The benefits of participating in CPA via political donations is well-researched in the market based accounting literature, with Cooper et al. (2010) observing that this helps corporations

\footnotetext{
${ }^{5}$ https://dhakabankltd.com/dhaka-bank-limited-handed-over-a-cheque-for-lakho-kontha-sonar-bangla-fund/
} 
form an association with the political regime of the country, and helps in maximizing stock returns. Due to the absence of a legal opportunity to directly contribute to political parties, corporations in Bangladesh appear to have used such CSR activities strategically to please powerful stakeholder groups - an ideal type for the market order, as identified by Thornton (2004). Interview evidence also indicates that the normative intent of DAR in promoting CSR activities in the banking sector was exploited by some banking companies to create a favorable impression and increase the visibility of the company to the government. Similarly, many banks distributed winter clothes in Gopalganj, the Prime Minister's electoral constituency located in southern Bangladesh, where the weather is normally warm. While interviewing the deputy director and executive director of the central bank, both mentioned:

"Apparently, only the people of Gopalganj (the hometown and the constitutional area of the Prime Minister) feel cold since most of the blankets and warm clothes tend to go there. (ExD1)"

In an interview with the press, a former deputy governor of the BB described these types of participation as efforts by PCBs to influence government policies:

'the owners of private banks give money to the government for various purposes, particularly for relief work during natural calamities. As a result, the owners of the banks have been able to exert pressure on the government to make the changes." (Exdeputy governor of BB, as reported in The Daily Star, 2017)

This is akin to Hillman and Hilt's (1999) definition of CPA, and is an ideal type for the market order.

There is further evidence of PCBs' efforts to strategically prioritize powerful stakeholder groups. Our analysis of the annual reports also reveals that companies made regular donations to two specific projects related to social inclusion and promotion of the rights of underprivileged children with autism. Notably, CSR contributions to autism were the highest in 2012, just after the daughter of the PM was appointed as the Chairman of the National Advisory Committee of Autism in 2011. The other recurring CSR activity in the annual reports of the organizations relates to contributions made to 'digital Bangladesh'. This project, explicitly mentioned in the election manifesto of the ruling party, is currently led by the PM's son. When asked about the motivations of organizations that engage in and report such activities, one respondent clearly stated, “what else, impressing the PM!” (MD4). 
We also found evidence that some politically appointed directors actually use the CSR guidelines of the Bangladesh Bank to maximize their own benefit. A director of a state- owned bank, a political nominee of the government, indicated that he distributed the bank's CSR money to poor freedom fighters in his own constituency, another election pledge of the ruling party:

"Me as a director distributed CSR money in my constituency, to the freedom fighters 6 there. I have participated in the election. I went to each freedom fighter's house and gave them money. I called them to my house and gave them money. I have taken pictures of all these. There are 600 pictures in Facebook. I also videotaped them"(ID2)

The list of the beneficiaries was published in the annual report of the bank. When asked specifically why he chose to conduct CSR activities in his constituency, he said,

"This is my area. I have to visit my village anyway. So, if I do CSR here, everybody knows me and I know everybody. This is a win-win situation. I help the poor people of my constituency and in return they will vote for me". (ID2)

A number of respondents noted the crucial role of the BAB in 'forcing' banks to participate in certain CSR activities. CSR disclosures in annual reports show that the Chairman of BAB was present on all occasions when funds were donated to the PM or BB Governor. Some respondents even claimed that in order to impress the PM and governor for his own personal benefit, the Chairman of BAB provides directives and guidelines for CSR in all sorts of crisis:

$B A B$ every moment comes (gives letters) and say give money... Come on ...this is the shareholder's money, you have no right to take this money and give it to whomever without concerning the shareholder or without explaining to me how this benefits the shareholders"(MD5)

Although the interviewees refused to comment on the exact motivation of the BAB in pursuing banks to engage in political CSR activities, media reports suggest that the organization has a strong influence on government policies. As mentioned before, in 2018, when the government passed a law allowing four members of a family to be directors of a bank, newspapers termed this a 'controversial bill, pursued by Bangladesh Association of Banks, an organization of the private bank owners since 2016' (New Age, 2018a).

\footnotetext{
6 'Freedom fighters' are members of the public who are widely respected for their participation in Bangladesh's liberation war in 1971.
} 
The PCBs' attitude towards engagement with CSR activities was neatly summarized by a CFO of a major commercial bank, who mentioned that the PCBs used the CSR regulations of the $\mathrm{BB}$ as a way to engage with $\mathrm{CPA}$ in order to maximize their self-interest:

'We have always provided 'chanda' (donations) to political parties, but there was no need to disclose these. However, since the Bangladesh Bank regulatory initiatives, the banks are having to spend a certain amount on CSR anyway. This gives us the scope to bring those donations in the guise of CSR activities, report them and gain tax exemptions' (DKB, CFO of a commercial bank)

This perhaps explains the rise in political CSR disclosure practices in Bangladesh. Although banks have been making donations to political parties in Bangladesh for a long time, this has always been in a rather covert form, as the legal environment in Bangladesh does not permit such donations. However, the tax exemptions for participation in some CSR activities that could be classified as political, led commercial banks to disclose these activities to claim the tax rebates. This seems to have led to the significant increase in political CSR in Bangladesh post-2009.

Overall, it appears that although the Bangladesh Bank's CSR regulatory guidelines were prompted by DAR's efforts to install the community logic within the banking sector, it did not transpire with PCBs. Rather, the PCBs used the regulatory interventions as a tool to engage in CPA to maximize their own interests, and to influence government policies in their own favour. Thus, for the PCBs, the order of the market appeared to be the dominant logic for engagement with CSR. Nevertheless, consistent with Thornton (2004), we also found the existence of other logics shaping some PCBs approach towards CSR. These are now discussed.

\subsection{The family logic for CPA}

Uddin et al. (2018) provided several examples of CSR disclosures where banks in Bangladesh made contributions in support of the ruling party's agenda and leaders' personal projects in the guise of CSR activities. That paper viewed such contributions as an attempt by corporations to bolster the ruling party's position in the wider society, and attributed this to Weber's (1947) notion of traditionalism. Weber (1947) identifies personal loyalty, obedience, obligations to a personal chief and being subject to a superior as key elements in maintaining a traditional society and its economic activities. These elements are similar to Thornton's depiction of ideal 
types for the order of family, where accountability and legitimacy is drawn from demonstrating unconditional loyalty towards the family.

Although our analysis suggests that the order of the market was the dominant logic for PCBs' participation in political activities in the guise of CSR, we also found several examples where banks participated in such activities in order to demonstrate unconditional loyalty to the ruling political regime. For example, Janata Bank Limited, actually published a book as part of its CSR reporting to commemorate the 'lakho konthe sonar bangla' event. The interviewee indicated that although the organization had an approved budged of Taka 1 million $^{7}$ for CSR activities, he had led initiatives to increase the budget to Tk 43 million, allowing the bank to participate in such events. It is worth mentioning that the Chairman of the Janata Bank is a nominee of the Prime Minister, essentially belonging to the 'political club', akin to an extended family. Thus, the interviewee would derive his legitimacy by demonstrating loyalty to the PM rather than through compliance with formal regulations, as the market logic would advocate. When asked about potential audit objections to this matter, the respondent laughed off such a possibility, mentioning that the auditors are fully aware of his political connections, and would not dare to raise any objection, given the political nature of the project. Similarly, another director of a commercial bank, who is also an active member of the ruling political party, commented that he was collecting money from corporations so that he could contribute to the PM's vision for a digital Bangladesh:

You know, I took donations from other companies and distributed in my village. I have given overhead projectors, laptops and computers to 35 schools. Those companies have given the money as CSR. This is how we can fulfill the dream of "Digital Bangladesh" (ID2)

We also found that several organizations, while not being politically connected, report CSR activities, which involve community work in the constituency of the political leaders of the ruling party. Interview evidence reveals that in many cases organizations accept these requests willingly due to their personal relationships with the political leader. One deputy-managing director of a large local corporate commented:

That day a member of the Parliament called me and said "Bhai, I am going to my constituency, will you be able to give 500 winter blankets for the villagers?" Well, then he said, you can give it to me, or you can directly give it through your branches. I gave

\footnotetext{
${ }^{7}$ Taka (Tk) is the Bangladeshi currency. As of February 1, 2020, 1 GBP= Tk 110.
} 
it and I did not think it as a pressure. It is ok. He is a minister; he is visiting his village and wanted some blankets from me. I would distribute the blankets anyway" (DMD2).

The reference to the word "bhai" (the Bengali word for 'brother', is used to depict a close relationship between two individuals) portrays the close, familial relationship between these individuals, indicative of a family logic for such political CSR.

Thus, it appears that in some cases, commercial banks engaged in mainstream political activities not to influence government policies, as the CPA literature would suggest. Rather, the Bangladesh Bank's CSR guidelines actually allowed the politically motivated executives of these banks to participate in activities that would enhance the image of their political leader.

\subsection{The existence of a community logic for CSR}

The analysis so far reveals the presence of a dominant market logic, but also the presence of a family logic guiding the approach of PCBs in Bangladesh towards political activities. However, during the course of our interviews, we found some PCB CSR activities that did not appear to be political. Rather, certain relatively rare CSR activities seem to be primarily rooted in the logic of community and appeared to be based on the personal upbringing and social stature of the family owners of these PCBs. For example, we found that one of the PCBs, the Mutual Trust Bank, is heavily engaged with community activities. This bank is owned by a pioneer of the footwear industry in Bangladesh, who is well respected and served in the cabinet of the interim caretaker government primarily due to his apolitical stance ${ }^{8}$. When asked about his motivations for CSR engagement, the chairman of this bank expressed his commitment to society:

I believe in doing good for the people who work for me and the community where I am located. I cannot do everything, so I will do CSR for the locality where I am working. For instance, may be by providing fresh water to the people there, or education for the children of the employees. (Chair, MTB)

\footnotetext{
${ }^{8}$ Between 1996 and 2008, the Bangladesh constitution allowed the formation of a caretaker government during the transition from one political government to the other. The cabinet members of the caretaker government did not represent any political party and were largely chosen from civil society.
} 
This PCB also appears to be one of the very few banks in Bangladesh that produce annual sustainability reports detailing the community engagements of the company. This is consistent with the ideal type of the community order, where accountability is demonstrated towards a wider group of stakeholders. The chairman also acknowledged that although the bank has been engaged in such activities for a long time, the Bangladesh Bank guidance on CSR did serve as a further impetus.

The Deputy Managing Director of another PCB mentioned that his bank has been actively engaged in CSR activities for a long time in education and the health sector. The bank provides a number of scholarships to students who are financially challenged. When asked about the motivations for the CSR, the DMD said:

'the board of directors are reputable people in our country and they have been doing business for a long time. So, they now want to do something good for the society' (DMD 1)

This suggests the presence of community logics in some PCBs that are primarily driven by the personal ethos and social reputation of the owners.

\section{Discussion}

The primary objective of this paper is to explore the emergence of CPA in banks in Bangladesh. As discussed, the high ownership concentration in the Bangladeshi corporate sector meant that prior to 2009 corporations, including banks, had no incentive to engage with CSR activities. Following the Bangladesh Bank's directive in 2009, the CSR disclosures in commercial banks in Bangladesh rose significantly. Uddin et al. (2018), however, report that many of such CSR activities were essentially of a political nature, raising questions about the banks' motivations. Interviews with policymakers, regulators, and top management in the banking industry reveal that the sudden increase in CSR disclosures in banks post-2009 followed regulatory interventions, primarily engineered by a new governor of the central bank who was driven by his personal ethos that banks have an obligation to society. However, for PCBs, such engagement appeared to have created an opportunity for maximizing self-interest, and in some cases, demonstrating loyalty to the political leadership. 
Our analysis reveals that these CSR regulatory interventions post-2009 were primarily influenced by a logic of community, based on the personal ethos of the newly appointed governor, DAR. As governor of the central bank, DAR held a legitimate bureaucratic subject position (Maguire et al, 2004), that enabled him to gain the necessary political and financial support to promote his own belief in creating a more inclusive and just society. In different meetings with the PCBs' management, he articulated the need for banks to participate in community development through their CSR activities. DAR also played an instrumental role in pushing regulatory interventions that mandated banks to spend a certain percentage of their profits on specified CSR activities, institutionalizing the emergence of CSR as an institutional practice for the banking sector in Bangladesh. Finally, as the governor of BB, DAR introduced an annual review of CSR activities conducted by the commercial banks, formalizing this new institutional practice. The use of the notion of 'ideal types' (Thornton, 2004) helped us identify the influence of institutional logics in the attitude of both Bangladesh Bank and the PCBs towards CSR. Table 3 summarizes the findings of this study in the context of the theoretical framing and methodology as discussed in earlier sections.

$<$ Table 3 around here $>$

Interviews with top executives of the commercial banks, however, reveal that although DAR's efforts may have been well-intentioned and rooted firmly in a community logic, many PCBs viewed this as an opportunity to maximize their self-interest by getting close to the ruling political regime, and eventually influencing government policies in their favour. Indeed, a large number of PCBs engaged in CSR that are primarily of a political nature, mainly in order to 'impress' the PM, or to maximize the personal political agenda of their owner-directors. Consistent with the definition of CPA, as provided by Hillman and Hilt (1999), our analysis indicates that professional associations, such as BAB played a key role in ensuring that CSR activities and disclosures by its member bodies are aligned with the political agenda of the ruling political party, allowing them to exert influence on government policies. Thus, the PCBs engagement with CPAs was primarily driven by the logic of market, whereby corporations strategically prioritize powerful stakeholders in a bid to maximize their own interest (Arena et al, 2018).

Consistent with prior CSR literature, we also find the existence of logical pluralism in the approach of certain PCBs towards CSR. In some cases, however, we find the presence of other social orders, such as family and community dictating the CSR activities of PCBs. Interview 
evidence reveals that in some cases, businesses have no personal gain from participating in such initiatives. Rather, the intention is to enhance the image of the ruling political party. Also, in some cases, requests from politicians for political donations in their constituencies in the guise of CSR were not seen negatively by corporate managers, as they considered the politicians to be part of their extended family. Overall, this suggests the presence of a family logic. This is consistent with Uddin et al. (2018), who state that Bangladeshi companies engage in CSR activities to primarily demonstrate their allegiance with the ruling political regime. As demonstrated in table 3, this is also akin to Thornton's (2004) depiction of an ideal type for the order of family, where CSR mechanisms are aimed at enhancing the reputation of the ruling political family. In certain cases, we also found some PCBs engaging in CSR activities with an intention to help the local community. It appears that the personal ethos and the reputation of family owners of these banks helped in the installation of a logic of community within these organizations that resulted in such community engagement via CSR.

Our study thus responds to previous calls for further research (for example, Belal and Owen, 2011) exploring the reasons why corporations in Bangladesh would want to engage with voluntary CSR activities. Our results are also consistent with recent studies such as Khan et al. (2020) that report that CSR activities in banks in Bangladesh are prompted by a quest to maintain effective relationships with other stakeholders, such as the government and political leaders. However, whereas Khan et al. (2020) uses Oliver's (1991) framework to investigate the strategic responses of banks to institutional practices, their study does not explicitly focus on the political nature of such disclosures. Rather, consistent with Uddin et al. (2018), the desire to satisfy political leadership is identified by Khan et al.(2020) as a major motivation behind CSR disclosures. The adoption of institutional logics as a theoretical lens for the purpose of the present paper allows us to extend these studies by demonstrating how the political nature of CSR practice has been shaped by existing logics within the organizations. Our analysis also lends empirical support to recent studies such as Mahmood and Uddin (2020), who, in an emerging economy context, identify the presence of multiple co-existing logics shaping the emergence of sustainability reporting practices. However, unlike Mahmood and Uddin (2020), we found that the CPA activities of the banking companies were primarily underpinned by a dominant market logic. However, in some cases, the logic of family and community also appeared to shape the nature of CSR disclosures, suggesting the presence of multiple logics within the industry. 


\section{Concluding remarks}

The primary objective of this study is to explore the emergence of CPA in the form of CSR in the Bangladeshi banking sector. Our analysis is based on 21 semi-structured interviews with top executives of commercial banks, major policymakers, such as Governors and ex-governors of the central bank, an ex-minister for finance, and representatives of civil society. We find that in general, commercial banks in Bangladesh have a significant political linkage, allowing them to exert influence on government policies. The presence of high ownership concentration and a weak capital market meant that banks traditionally had no incentive to participate in CSR activities. However, the policy intervention made by the GoB in 2009 worked as a major game changer for the corporate sector to participate in CSR activities. This policy intervention coincided with the appointment of a new governor who was sincere and serious about making commercial banks contribute to the greater social cause. Subsequently, the central bank played a major role in encouraging commercial banks to engage with CSR activities. The use of institutional logics as a framework of analysis helps us identify the role of the governor of the central bank as an institutional entrepreneur (DiMaggio, 1981). Using Maguire et al.'s (2004) framework, we find that as the governor of the central bank, DAR used his bureaucratic subject position to engage in persuasive argumentation and political negotiations that eventually led to the emergence of CSR activities as a new institutional practice in the banking sector in Bangladesh.

Interviews with respondents, however, reveal that although DAR's approach towards introduction of CSR activities in banks was driven by a logic of community, the attitude of commercial banks towards this new practice was shaped by the existing logics within respective organizations. Thus, many banks actually saw this initiative as an opportunity to maximize their self-interest, giving rise to CPA in the banking sector in Bangladesh. Consistent with prior literature (Arena et al, 2018), we find that the banking sector's approach towards CSR activities was influenced by the presence of logical pluralism of market, family and community. Our finding has important implications for policymakers in developing countries, as it demonstrates how well-intentioned policies formulated at the top can sometimes be exploited and abused by actors within an industry who may sometimes view such regulatory interventions as an opportunity to pursue their own goals, especially where the context involves the absence of complete institutions. 
We contribute to the accounting and management literature on the political nature of CSR. Within accounting academia, our study is amongst the first to explore the emergence of CPA, and the role of institutional entrepreneurs in the context of a developing economy. Bebbington et al. (2008) note that within the accounting literature, many authors have used legitimacy theory as an explanatory framework for CSR disclosure. However, a number of studies (O’Dwyer 2003; Parker, 2005) have hinted about the possibilities of more diverse explanations of CSR engagement and disclosure, taking into account the complexities of the external and internal factors that affect such activities. Contrary to Uddin et al. (2018), our study suggests that the approach of the Bangladeshi corporate sector towards CSR activities is not driven only by the family logic (or the notions of traditionalism, as argued by Uddin et al, 2018). Rather, the corporate sector's approach towards CSR engagement and disclosure is driven by multiple logics. The adoption of an alternative theoretical framework, therefore, allow us to extend Uddin et al. (2018)'s study by providing evidence of the presence of logical pluralism across the banking industry in the manner it engages with CSR activities and disclosures, and by explaining the underlying motivations for political CSR in Bangladesh Also, although previous studies (Glynn and Rafaelli, 2013) acknowledge the role of logical pluralism in the manner CSR practices are embedded within organizational structures, they identified market and community logics as the primary driver for the adoption of CSR practices. In our case, we find that CSR practices in Bangladesh emphasized the presence of a dominant market logic, along with, family and community logics. By also focusing on the central bank's approach towards CSR regulation, we contribute to the CSR literature that is primarily concerned with the firm's response to regulatory interventions. 


\section{References:}

AAAJ (2018), "Call for papers: Incorporating Context into Social and Environmental Accounting (SEA) in Developing Nations", Accounting, Auditing and Accountability Journal.

ADB (2003), "ADB report on Bangladesh capacity building of the Securities and Exchange Commission and selected capital market institutions", Dhaka, Bangladesh.

Adly, A.I. (2009), "Politically-embedded cronyism: the case of post-liberalization Egypt", Business and Politics, Vol. 11, No. 4, pp. 1-26.

Ahmed, S. ( 2015), "Large loan restructuring policy: criticisms and answers", The Daily Star, 2 July, 2015.

Amans, P., Mazars-Chapelon, A., and Villesèque-Dubus, F. (2015), "Budgeting in institutional complexity: The case of performing arts organizations", Management Accounting Research, Vol. 27, pp. 47-66.

Antonio, R. J. and Glassman, R. M. (1985), “A Weber-Marx Dialogue”, Lawrence KS: University of Kansan Press.

Arena, M., Azzone, G., and Mapelli, F. (2018), "What drives the evolution of Corporate Social Responsibility strategies? An institutional logics perspective", Journal of cleaner production, Vol. 171, pp. 345-355.

Auyeung, P. and Ivory, P. (2003), "A Weberian model applied to the study of accounting stagnation in late Qing China", Accounting, business \& financial history, Vol.13, No. 3, pp. 5- 26.

Baines, P. and Viney, H. (2010), "The unloved relationship? Dynamic capabilities and political-market strategy: a research agenda", Journal of Public Affairs, Vol. 10, pp. 258- 264.

Baysinger, B. (1984), "Domain maintenance as an objective of business political activity: an expanded typology", Academy of Management Review, Vol. 9, pp. 248-258.

Bangladesh Bank (2008), "Mainstreaming corporate social responsibility in banks and financial institutions in Bangladesh, DOS circular no. 1, Department of Off-site Supervision, Dhaka.

Bangladesh Bank (2010), "Review of CSR Initiatives in Banks-2010”. Dhaka: Bangladesh Bank.

Baron, D.P. (1997), "Integrated strategy in international trade disputes. The Kodak-Fujifilm case", Journal of Economics and Management Strategy, Vol.6, pp. 291-346.

Blanc, R., Islam, M. A., Patten, D. M., and Branco, M. C. (2017), "Corporate anti-corruption disclosure: An examination of the impact of media exposure and country-level press freedom.", Accounting, Auditing \& Accountability Journal, Vol. 30, No. 8, pp.1746-1770.

Bebbington, J., Larrinaga, C., and Moneva, J. M. (2008), "Corporate social reporting and reputation risk management", Accounting, Auditing \& Accountability Journal.

Belal, A. R. (2001), "A study of corporate social disclosures in Bangladesh", Managerial Auditing Journal, Vol. 16, No. 5, pp. 274-289. 
Belal, A. R. and Owen, D. L. (2007), "The views of corporate managers on the current state of, and future prospects for, social reporting in Bangladesh", Accounting, Auditing \& Accountability Journal, Vol. 20, No. 3, pp. 472-494.

Belal, A. R. and Roberts, R. W. (2010), "Stakeholders' perceptions of corporate social reporting in Bangladesh", Journal of Business Ethics, Vol. 97, No. 2, pp. 311-324.

Berglöf, E. and Claessens, S. (2006), "Enforcement and good corporate governance in developing countries and transition economies", The World Bank Research Observer, Vol. 21, pp. 123-150.

Bonardi, J. P., Holburn, G. L., and Vanden Bergh, R. G. (2006), "Nonmarket strategy performance: Evidence from US electric utilities", Academy of Management Journal, Vol.49, No. 6, pp.1209-1228.

Brubaker, R. (1984), “The Limits of Rationality”, Boston, MA: George Allen \& Unwin, 1984.

Burawoy, M. (1985), "The politics of production: Factory regimes under capitalism and Socialism”, Verso Books.

Byrch, C., Milne, M. J., Morgan, R., and Kearins, K. (2015), “Seeds of hope? Exploring business actors' diverse understandings of sustainable development", Accounting, Auditing \& Accountability Journal, Vol. 28, No. 5, pp. 671-705.

Canning, M., and O'Dwyer, B. (2016), "Institutional work and regulatory change in the accounting profession", Accounting, Organizations and Society, Vol. 54, pp.1-21.

Caramanis, C. V. (2005), "Rationalisation, charisma and accounting professionalization: perspectives on the intra-professional conflict in Greece, 1993-2001", Accounting, Organizations and Society, Vol. 30, No. 3, pp. 195-221.

Carlsson-Wall, M., Kraus, K., and Karlsson, L. (2017), "Management control in pulsating organisations-A multiple case study of popular culture events", Management Accounting Research, Vol. 35, pp. 20-34.

Carroll, A. B., and Shabana, K. M. (2010), "The business case for corporate social responsibility: A review of concepts, research and practice", International journal of management reviews, Vol. 12, No.1, pp. 85-105.

Chapple, W. and Moon, J. (2007), "CSR agendas for Asia", Corporate Social Responsibility and Environmental Management, Vol. 14, No. 4, pp.183-188.

Chua, W. F., (1986), "Radical developments in accounting thought”, Accounting review, pp. 601-632.

Chua, W. F. and Poullaos, C. (1998), "The dynamics of "closure" amidst the construction of market, profession, empire and nationhood: An historical analysis of an Australian accounting association, 1886-1903", Accounting, Organizations and Society, Vol. 23, No. 2, pp. 155-187.

Clegg, S.R. (1989), "Radical revisions: Power, discipline and organizations", Organization studies, Vol. 10, No. 1, pp. 97-115.

Colignon, R. and Covaleski, M. (1991), "A Weberian framework in the study of accounting", Accounting, Organizations and Society, Vol. 16, No.2, pp.141-157.

Collins, R. and Turner, J. H. (1986), “Max Weber: A skeleton key”, Sage Newbury Park, CA. 
Cooper, M. J., Gulen, H., and Ovtchinnikov, A. V. (2010), "Corporate political contributions and stock returns", The Journal of Finance, Vol. 65, No. 2, pp. 687-724.

Crane, A., Matten, D., Moon, J. and Moon, J. (2008), "Corporations and citizenship", Cambridge University Press Cambridge.

Daily Sun (2015), 'Banker for the poor', October 16. Available at: https://www.dailysun.com/magazine/details/83437/Banker-of-the-Poor/2015-10-16 (accessed on October 4, 2020)

Deegan, C., and Blomquist, C. (2006), "Stakeholder influence on corporate reporting: An exploration of the interaction between WWF-Australia and the Australian minerals industry", Accounting, Organizations and Society, Vol. 31, No.(4-5), pp. 343-372.

Dhaka Tribune (2018), “ Bill allowing 4 family members on bank board passed”, 6 January. Available at: $\quad$ https://www.dhakatribune.com/bangladesh/2018/01/16/bill-allowing-4-family-members-bankboard-passed (accessed on October 4, 2020).

Dhaka Tribune (2018a), ' Banking sector must steer clear of political influence'. Available at: https://www.dhakatribune.com/business/banks/2018/12/09/economists-banking-sector-must-steerclear-of-political-influence (accessed on October 4, 2020)

Dhaliwal, D. S., Li, O. Z., Tsang, A. and Yang, Y. G. (2011), "Voluntary nonfinancial disclosure and the cost of equity capital: The initiation of corporate social responsibility reporting", The Accounting Review, Vol. 86, No. 1, pp.59-100.

DiMaggio, P. (1988), "Interest and agency in institutional theory", In L. Zucker (Ed.), Institutional patterns and culture (pp. 3-32). Cambridge, MA: Ballinger.

DiMaggio, P. (1998), “The new institutionalisms: avenues of collaboration", Journal of Institutional and Theoretical Economics (JITE)/Zeitschrift für die gesamte Staatswissenschaft, Vol. 154, No. 4, pp. 696-705.

Donald V. Moser and Patrick R. Martin. (2012), "A Broader Perspective on Corporate Social Responsibility Research in Accounting", The Accounting Review, Vol. 87, No. 3, pp. 797-806. https://doi.org/10.2308/accr-10257

Dunn, M. B., and Jones, C. (2010), "Institutional logics and institutional pluralism: The contestation of care and science logics in medical education, 1967-2005", Administrative science quarterly, Vol.55, No. 1, pp. 114-149.

Dyball, M. C., Chua, W. F. and Poullaos, C. (2006), "Mediating between colonizer and colonized in the American empire: Accounting for government moneys in the Philippines", Accounting, Auditing \& Accountability Journal, Vol.19, No.1, pp. 47-81.

Dyball, M. C. and Valcarcel, L. J. (1999), "The "rational" and "traditional": the regulation of accounting in the Philippines", Accounting, Auditing \& Accountability Journal, Vol. 12, No. 3, pp. 303-328.

Ezzamel, M., Robson, K., and Stapleton, P. (2012), "The logics of budgeting: Theorization and practice variation in the educational field", Accounting, organizations and society, Vol. 37, No.5, pp. 281-303.

Farooque, O. A., Van Zijl, T., Dunstan, K. and Karim, A. (2007), "Corporate governance in Bangladesh: link between ownership and financial performance", Corporate governance: An international review, Vol. 15, pp. 1453-1468. 
Friedland, R. and Alford, R. R. (1991), "Bringing society back in: Symbols, practices, and institutional contradictions. In W.W. Powell \& P.J. DiMaggio (Eds.)” The New Institutionalism in Organizational Analysis, pp. 232-263. Chicago: the University of Chicago Press.

Frynas, J. G., and Stephens, S. (2015), "Political corporate social responsibility: Reviewing theories and setting new agendas", International Journal of Management Reviews, Vol. 17, No. (4), pp. 483509.

Gao, J., and Bansal, P. (2013), "Instrumental and integrative logics in business sustainability", Journal of Business Ethics, Vol. 112, No.2, pp. 241-255.

Garud, R., and Karnøe, P. (2001), "Path creation as a process of mindful deviation" Path dependence and creation, 138.

Greenwood, R., Suddaby, R., and Hinings, C. R. (2002), "Theorizing change: The role of professional associations in the transformation of institutionalized fields", Academy of management journal, Vol. 45, Issue (1), pp. 58-80.

Glynn, M. A., and Raffaelli, R. (2013), "Logic pluralism, organizational design, and practice adoption: The structural embeddedness of CSR programs", Research in the Sociology of Organizations B, Vol. 39, pp. 175-197.

Guest, G., Bunce, A. and Johnson, L., (2006), "How many interviews are enough? An experiment with data saturation and variability", Field methods, Vol. 18, pp. 59-82

GOB (1994), Government of the People's Republic of Bangladesh, The Companies Act 1994, Act No. 18 of 1994.

GoB (2008), “Tax rebate on corporate social responsibility expenditures”, SRO 270- Law/2009, National Board of Revenue, Government of Bangladesh, Dhaka.

Gu, H., Ryan, C., Bin, L. and Wei, G. (2013), "Political connections, guanxi and adoption of CSR policies in the Chinese hotel industry: Is there a link"? Tourism Management, Vol.34, pp. 231-235.

Glynn, M. A., and Raffaelli, R. (2013), "Logic pluralism, organizational design, and practice adoption: The structural embeddedness of CSR programs", Research in the Sociology of Organizations B, Vol. 39, pp.175-197.

Hackston, D. and Milne, M. J. (1996), "Some determinants of social and environmental disclosures in New Zealand companies", Accounting, Auditing \& Accountability Journal, Vol. 9, pp. $77-108$.

Halme, M. (2002), "Corporate environmental paradigms in shift: Learning during the course of action at UPM-Kymmene", Journal of Management Studies, Vol. 39, No. 8, pp. 1087-1109.

Hasan, M. (2018), “Economists: banking sector must steer clear of political influence”, Dhaka Tribune, 9 December.

Higgins, C., Stubbs, W. and Love, T. (2014), "Walking the talk (s): Organizational narratives of integrated reporting", Accounting, Auditing \& Accountability Journal, Vol.27, pp. 1090-1119.

Hillman, A.J. and Hitt, M.A. (1999), "Corporate political strategy formulation: a model of approach, participation and strategy decisions", Academy of Management Review, Vol. 24, pp. 825-842. 
Hillman, A.J., Zarkhoodi, A. and Bierman, L. (1999), "Corporate political strategies and firm performance: indications of firm-specific benefits from personal service in the U.S. Government", Strategic Management Journal, Vol. 20, pp. 67-81.

Hindess, B. (1987), "Rationality and the characterization of modern society", in Whimster, S.\& Lash, S (eds) Max Weber, Rationality and Modernity, pp.137-153. Boston MA: Allen \& Unwin, 1987.

Henisz, W. J. and Zelner, B. A. (2003), "The strategic organization of political risks and opportunities", Strategic Organization, Vol.1, pp. 451-460.

Hoskisson, R. E., Eden, L., Lau, C. M. and Wright, M. (2000), "Strategy in emerging economies", Academy of management journal, Vol. 43, pp. 249-267.

Hsieh, N.-H. (2009), "Corporate Social Responsibility and the Priority of Shareholders", Journal of Business Ethics, Vol. 88, pp.553-560.

Humphrey, C. E. (1987), "Privatization in Bangladesh. Centre for Privatizatio"n, US Agency for International Development, Washington DC.

Ioannou, I., and Serafeim, G. (2015), "The impact of corporate social responsibility on investment recommendations: Analysts' perceptions and shifting institutional logics", Strategic Management Journal, Vol. 36, No. 7, pp. 1053-1081.

Islam, M. A. and Deegan, C. (2008), "Motivations for an organization within a developing country to report social responsibility information: Evidence from Bangladesh", Accounting, Auditing \& Accountability Journal, Vol. 21, pp. 850-874.

Islam, T. (2020), “NPL and its impact on the banking sector of Bangladesh", The Financial Express, 21 July.

Institute of Governance Studies. (2008), "The state of governance in Bangladesh in 2007: Expectations, commitments and challenges. Bangladesh": BRAC University.

Jaggi, B., and Zhao, R. (1996), "Environmental performance and reporting: perceptions of managers and accounting professionals in Hong Kong", The international journal of accounting, Vol. 31, No. 3, pp. 333-346.

Johnson, H. T. and Kaplan, IL S. (1987), "Relevance Lost. The Rise and Fall of Management Accounting", (Boston, MA: Harvard University Press, 1987)

Jones, M., Solomon, J., and Siddiqui, J. (2013), "Mainstreaming biodiversity accounting: potential implications for a developing economy", Accounting, Auditing \& Accountability Journal.

Kaplan, IL S. and Cooper, IL C. (1987), "How Cost Accounting Systematically Distorts Product Costs", in Bums, W.J. \& Kaplan, IL S. (eds) Accounting and Management. Field Studies, Chapter 8 (Boston, MA: Harvard Business School Press)

Khan, H.U.Z, Bose, S. and Jones, R. (2020). Regulatory influences within CSR practices within banks in an emerging economy: do banks merely comply, Critical Perspectives on Accounting Vol. 21, pp. 120.

Khan, H. U. Z. (2010), "The effect of corporate governance elements on corporate social responsibility (CSR) reporting: Empirical evidence from private commercial banks of Bangladesh", International Journal of Law and Management, Vol. 52, pp. 82- 109 
Khan, A., Muttakin, M.B. and Siddiqui, J. (2013), "Corporate governance and corporate social responsibility disclosures: Evidence from an emerging economy", Journal of Business Ethics, Vol.114, No. (2), pp.207-223.

Khan, A., Muttakin, M. B., and Siddiqui, J. (2015), "Audit fees, auditor choice and stakeholder influence: Evidence from a family-firm dominated economy", The British Accounting Review, Vol. 47, No. (3), pp. 304-320.

Khan, M. M. (2003), "State of governance in Bangladesh”, The Round Table, Vol. 92, No.370, pp. 391405 .

Kim, Y. C., and Chung, C. N. (2018), "Organizational change under institutional logics: Family control of corporate boards in Taiwan”, Sociological Perspectives, Vol. 61, No.3, pp. 444-466.

King, N. and Horrocks, C. (2010), "Interviews in qualitative research”, Sage.

King, A. (1994), "Guiding knowledge construction in the classroom: Effects of teaching children how to question and how to explain", American educational research journal, Vol. 31, No. 2, pp. 338-368.

Kochanek, S. A. (1996), “The rise of interest politics in Bangladesh", Asian Survey, Vol. 36, pp. 704 722 .

Kvale, S., and Brinkmann, S. (2009). Interviews: Learning the craft of qualitative research interviewing. Sage.

Lawrence, T. (1999), “Institutional strategy”, Journal of Management, Vol. 25, pp. 161-188.

Lawton, T., McGuire, S., and Rajwani, T. (2013), "Corporate political activity: A literature review and research agenda”, International Journal of Management Reviews, Vol.15, No. 1, pp. 86-105.

Lord, M. D. (2003), "Constituency building as the foundation for corporate political strategy", The Academy of Management Executive, Vol. 17, pp. 112-124.

Lux, S., Crook, T. R. and Woehr, D. J. (2011), "Mixing business with politics: A meta-analysis of the antecedents and outcomes of corporate political activity", Journal of Management, Vol.37, pp. 223247.

Maak, T., Pless, N. M., and Voegtlin, C. (2016), "Business statesman or shareholder advocate? CEO responsible leadership styles and the micro-foundations of political CSR", Journal of Management Studies, Vol. 53, No. 3, pp. 463-493.

Maguire, S, Cynthia, H., and Thomas L. (2004), "Institutional entrepreneurship in emerging fields: HIV/AIDS treatment advocacy in Canada", Academy of Management Journal, Vol.47, No.5, pp. 657679.

Mahmood, Z. and Uddin, S. (2020), "Institutional logics and practice variations in sustainability reporting: evidence from an emerging field", Accounting, Auditing \& Accountability Journal.

Mathews, M. R. (1997), "Twenty-five years of social and environmental accounting research: is there a silver jubilee to celebrate"? Accounting, Auditing \& Accountability Journal, Vol.10, pp. 481-531.

Matten, D., and Moon, J. (2008), "Implicit" and "explicit" CSR: A conceptual framework for a comparative understanding of corporate social responsibility, The Academy of Management Review, Vol. 33, No. 2, 404-424. http://dx.doi.org/10.2307/20159405 
Milne, M. J. and Gray, R. (2013), "W(h)ither ecology? The triple bottom line, the global reporting initiative, and corporate sustainability reporting", Journal of Business Ethics, Vol. 118, pp. 13-29.

Momin, M. A. and Parker, L. D. (2013), "Motivations for corporate social responsibility reporting by MNC subsidiaries in an emerging country: The case of Bangladesh", The British Accounting Review, Vol. 45, pp. 215-228.

Morck, R. and Steier, L. (2005), "The global history of corporate governance: An introduction", $A$ history of corporate governance around the world: Family business groups to professional managers, University of Chicago Press.

Muthuri, J. N. and Gilbert, V. (2011), “An Institutional Analysis of Corporate Social Responsibility in Kenya”, Journal of Business Ethics, Vol. 98, pp. 467-483.

Muttakin, M. B., Mihret, D. G. and Khan, A. (2018), "Corporate Political Connection and Corporate Social Responsibility Disclosures: A neo-pluralist hypothesis and empirical evidence", Accounting, Auditing \& Accountability Journal, Vol. 31,pp. 725-744, https://doi.org/10.1108/AAAJ-06-2015-2078

New Age (2020). 'Banks donate to PM's relief fund to combat coronavirus. April 05. Available at: https://www.newagebd.net/article/103875/banks-donate-tk-14773cr-to-pms-relief-fund-to-combatcoronavirus (accessed on October 4, 2020)

New Age ( 2018a), “Banks to have 4 of a family as directors", 17 January. Available at: http://www.newagebd.net/article/32721/banks-to-have-4-of-a-family-as-directors (accessed on October 4, 2020)

New Age ( 2018), " 3 more banking licenses to be granted on political ground: Muhith”, 2 November, available at: https://www.newagebd.net/article/54783/3-more-banking-licences-to-be-granted-onpolitical-ground-muhith (accessed on October 4, 2020).

O’Dwyer, B. (2003), "Conceptions of corporate social responsibility: the nature of managerial capture", Accounting, Auditing \& Accountability Journal.

O’Dwyer, B. (2004), "Qualitative data analysis: illuminating a process for transforming a 'messy'but 'attractive' "nuisance' ". The real life guide to accounting research: A behind-the-scenes view of using qualitative research methods, pp. 391-407.

O'Dwyer, B., and Owen, D. L. (2005), "Assurance statement practice in environmental, social and sustainability reporting: a critical evaluation", The British Accounting Review, Vol. 37, No.2, pp. 205 229.

O'Dwyer, B., Unerman, J. and Bradley, J. (2005), "Perceptions on the emergence and future development of corporate social disclosure in Ireland: Engaging the voices of non governmental organizations", Accounting, Auditing \& Accountability Journal, Vol. 18, pp. 14-43.

Oliver, C. (1990), "Determinants of interorganizational relationships: Integration and future directions", Academy of management review, Vol. 15, No.2, pp.241-265.

Parker, L. D. (2005), "Social and environmental accountability research", Accounting, Auditing \& Accountability Journal.

Prechel, H. and Morris, T. (2010), "The Effects of Organizational and Political Embeddedness on Financial Malfeasance in the Largest U.S. Corporations", American Sociological Review, Vol. 75, pp. 331-354. 
Quadir, F. (2003), "How "Civil" is Civil Society? Authoritarian State, Partisan Civil Society, and the Struggle for Democratic Development in Bangladesh", Canadian Journal of Development Studies/Revue canadienne d'études du développement, Vol. 24, pp. 425-438.

Quattrone, P. (2006), "The possibility of the testimony: A case for case study research", Organization, Vol.13, No. 1, pp.143-157.

Radcliffe, V. S. (1997), "Competing rationalities in "special" government audits: the case of Novatel", Critical Perspectives on Accounting, Vol.8, pp.343-366.

Rahman, S (2014), “ CSR Guideline drafted”, The Daily Star, 15 September. https://www.thedailystar.net/csr-guideline-drafted-41686

Roulston, K. (2010), Reflective interviewing: A guide to theory and practice. Sage.

Jiang, R. J., and Bansal, P. (2003), "Seeing the need for ISO 14001”, Journal of Management Studies, Vol. 40, No. 4, pp. 1047-1067.

Russell, J. (1985), "Methods, Analysis, and Politics in Max Weber: Disentangling Marxian Affinities and Differences", History of Political Economy, pp.575-590.

Scherer, A. G. and Palazzo, G. (2007), "Toward a political conception of corporate responsibility: Business and society seen from a Habermasian perspective", Academy of management review, Vol. 32, pp. 1096-1120.

Scherer, A. G. and Palazzo, G. (2011), "The new political role of business in a globalized world: A review of a new perspective on CSR and its implications for the firm, governance, and democracy", Journal of management studies, Vol. 48, pp. 899-931.

Scherer, A., Palazzo, G. and Baumann, D. (2006), "Global rules and private actors-Towards a new role of the transnational corporation in global governance", Business Ethics Quarterly, Vol. 16, pp. 505532.

Scherer, A. G., Palazzo, G. and Matten, D. (2009), "Introduction to the special issue: Globalization as a challenge for business responsibilities", Business Ethics Quarterly, Vol. 19, pp. 327-347.

Scherer, A. G., Palazzo, G., and Matten, D. (2014), "The business firm as a political actor: A new theory of the firm for a globalized world", Business \& Society, Vol. 53, No. 2, pp.143-156.

Scherer, A. G., Rasche, A., Palazzo, G., and Spicer, A. (2016), "Managing for political corporate social responsibility: New challenges and directions for PCSR 2.0." Journal of Management Studies, Vol. 53, No. 3, pp. 273-298.

Schluchter, W. (1979), "The Paradox of Rationalization: On the Relation of Ethics and World", in Roth, G. \& Schluchter, W (eds) Max Weber's Vision of History pp. 11-64. Berkeley, CA: University of California Press.

Schutz, K. (1967), “The Phenomenology of the Social World”, (Evanston, IL: Northwestern University Press).

Scott, W. R., Ruef, M., Mendel, P. J., and Caronna, C. A. (2000), "Institutional change and healthcare organizations: From professional dominance to managed care", University of Chicago Press. 
Shank, G. D. (2002), "Qualitative research: A personal skills approach”, Prentice Hall Englewood Cliffs, NJ

Siddiqui, J. (2010), "Development of corporate governance regulations: The case of an emerging economy”, Journal of Business Ethics, Vol. 91, No. 2, pp. 253-274.

Siddiqui, J. and Uddin, S. (2016), "Human rights disasters, corporate accountability and the state: Lessons learned from Rana Plaza", Accounting, Auditing \& Accountability Journal, Vol. 29, pp. 679704.

Siddiqui, J., Yasmin, S., and Humphrey, C. (2019), "Stumped! The limits of global governance in a commercialized world of cricket", Accounting, Auditing \& Accountability Journal 32(7), pp. 18981925.

Siddiqui, J., McPhail, K. and Rahman, S.S. (2020), "Private governance responsibilisation in global supply chains: the case of Rana Plaza", Accounting, Auditing \& Accountability Journal.

Sinkovics, N., Hoque, S. F. and Sinkovics, R. R.(2016), "Rana Plaza collapse aftermath: are CSR compliance and auditing pressures effective?" Accounting, Auditing \& Accountability Journal, Vol. 29, pp. 617-649.

Silverman, D. and Marvasti, A. (2008), "Doing qualitative research: A comprehensive guide", Sage.

Simons, H. (2009), “Case study research in practice”, SAGE publications.

Sobhan, R. (1980), "Growth and Contradictions Within the Bangladesh Bourgeoisie". Journal of Social Studies, Vol. 9, pp.1-27.

Sobhan, R. and Ahmad, M. (1980), "Public enterprise in an intermediate regime: a study in the Political Economy of Bangladesh", JSTOR.

Tan, L., and Wang, N. (2010), "Future internet: The internet of things" In 2010 3rd international conference on advanced computer theory and engineering (ICACTE), Vol. 5, pp. V5-376. IEEE.

The Daily Star (2014), 'CSR guideline drafted', September 15, available at: https://www.thedailystar.net/csr-guideline-drafted-41686 (accessed on December 17, 2020).

The Daily Star (2014a, 'Logo of lakho konthe shonar bangla unveilled', March 3. Available at: https://www.thedailystar.net/logo-of-lakho-konthe-shonar-bangla-unveiled-13730 (accessed on December 17, 2020).

The Daily Star (2015), 'Large loan restructuring policy', June 2, available at: https://www.thedailystar.net/business/banking/large-loan-restructuring-policy-criticisms-and-answers89992 (accessed on October 4, 2020).

The Daily Star (2017), “ Bankers to go in family grips”, May 9. Available at: https://www.thedailystar.net/frontpage/banks-go-family-grips-1402777 (accessed on October 4, 2020)

The Daily Star (2019a), 'Bailout for big loan defaulters', May 18, available at: https://www.thedailystar.net/frontpage/news/bangladesh-bank-bailout-big-loan-defaulters-1716697 (accessed on October 4, 2020).

The Daily Star (2019b),' Parliament of millionaires', January 17. Available at https://www.thedailystar.net/bangladesh-national-election-2018/61.07-percent-elected-mp-arebusiness-persons-shujan-1683718 (accessed on October 4, 2020). 
The Financial Express (2009), “Atiur Rahman made 10 ${ }^{\text {th }}$ BB Governor”, 30 April.

The Financial Express (2009), "PM asks private banks to open branches in rural areas", July 1.

The Financial Express (2020). 'NPL and its impact on the banking sector in Bangladesh'. Available at: https://thefinancialexpress.com.bd/views/npl-and-its-impact-on-the-banking-sector-of-bangladesh1595343188 (accessed on October 04, 2020).

The World Bank (2019), "Bank non performing loans to total gross loan (\%)", IMF, Global Financial Stability Report, available at: https://data.worldbank.org/indicator/FB.AST.NPER.ZS?name desc=false\&view=map

Thornton, P. H., and Ocasio, W. (1999), "Institutional logics and the historical contingency of power in organizations: Executive succession in the higher education publishing industry", 1958-1990. American journal of Sociology, Vol. 105, Issue (3), pp. 801-843.

Thornton, P. H. (2004). Markets from culture: Institutional logics and organizational decisions in higher education publishing. Stanford University Press.

Thornton, P. H., Ocasio, W., and Lounsbury, M. (2012), “The institutional logics perspective”, Oxford: Oxford University Press.

Thornton, P. H. (2004), "Markets from culture: Institutional logics and organizational decisions in higher education publishing", Stanford University Press.

Tsang, E. W. (1998), "A longitudinal study of corporate social reporting in Singapore: The case of the banking, food and beverages and hotel industries", Accounting, Auditing \& Accountability Journal, Vol. 11, pp. 624-635.

Tregidga, H., Milne, M. and Kearins, K. (2014), (Re) presenting 'sustainable organizations", Accounting, Organizations and Society, Vol. 39, pp. 477-494.

Uddin, S. (2009), "Rationalities, domination and accounting control: A case study from a traditional society", Critical Perspectives on Accounting, Vol. 20, pp. 782-794.

Uddin, S. and Choudhury, J. (2008), "Rationality, traditionalism and the state of corporate governance mechanisms: Illustrations from a less-developed country", Accounting, Auditing \& Accountability Journal, Vol. 21, pp. 1026-1051.

Uddin, S. and Hopper, T. (2001), "A Bangladesh soap opera: privatisation, accounting, and regimes of control in a less developed country", Accounting, organizations and society, Vol. 26, pp. 643-672.

Uddin, S. and Hopper, T. (2003), "Accounting for privatisation in Bangladesh: testing World Bank claims" Critical Perspectives on Accounting, Vol. 14, pp. 739-774.

Uddin, S., Siddiqui, J. and Islam, M. A. (2018), "Corporate Social Responsibility Disclosures, traditionalism and Politics: A Story from a Traditional Setting”, Journal of Business Ethics, Vol. 151, No. 2, pp. 409-428

Unsal, O., Hassan, M. K., and Zirek, D. (2016), "Corporate lobbying, CEO political ideology and firm performance”, Journal of Corporate Finance, Vol. 38, pp. 126-149. 
Van Maanen, J. (1979), "The fact of fiction in organizational ethnography", Administrative science quarterly, Vol, 24, No. (4), pp. 539-550.

Walker, E. T., and Rea, C. M. (2014), “The political mobilization of firms and industries", Annual review of sociology, Vol. 40, pp. 281-304.

Weber, M. (1923), “GAteS, II” (Hinduismus and Buddhismus), pp.1-398.

Weber, M. (1947), "The theory of economic and social organization" Trans. AM Henderson and Talcott Parsons. New York: Oxford University Press.

Weber, M. (1978), "Economy and society: An outline of interpretive sociology", University of California Press.

Weber, M. (1981), “General economic history”, Transaction publishers.

Whelan, G. (2012), "The political perspective of corporate social responsibility: A critical research agenda", Business Ethics Quarterly, Vol. 22, pp.709-737.

Wickramasinghe, D. and Hopper, T. (2005), "A cultural Political Economy of management accounting controls: a case study of a textile Mill in a traditional Sinhalese village", Critical Perspectives on Accounting, Vol.16, pp. 473-503.

Wiley, N. (1987), "Introduction, in Wiley, N. (ed.) The Marx-Weber Debate: Key Issues in Sociological Theory", pp. 7-27. Beverly Hills: Sage.

Willmott, H. C. (1983), "Paradigms for accounting research: Critical reflections on Tompkius and Groves' 'Everyday accountant and research his reality", Accounting Organization, and Society, pp. 389406.

Yadav, V. (2011), "Political parties, business groups, and corruption in developing countries", Oxford University Press.

Yeo, G. T., Ng, A. K., Lee, P. T. W., and Yang, Z. (2014), "Modelling port choice in an uncertain environment", Maritime Policy \& Management, Vol. 41, No.3, pp. 251-267.

Zaman,I. (2011), “Corruption and Anti Corruption in Bangladesh. Dhaka”, Transparency International of Bangladesh. 
Table 1: List of interviewees

\begin{tabular}{|c|c|c|c|}
\hline Serial & Interviewee Designation & Category & Code \\
\hline 1. & Former Governor, Central Bank & Policy Maker & SUA \\
\hline 2. & $\mathrm{CFO}$ & Commercial Bank & DKB \\
\hline 3. & Former Governor, Central Bank & Policy Maker & DAR \\
\hline 4. & $\begin{array}{l}\text { Former Deputy Governor, Central } \\
\text { Bank }\end{array}$ & Policy Maker & AMK \\
\hline 5. & Executive Director, Central Bank & Regulator & EXD 1 \\
\hline 6. & Deputy Director, Central Bank & Regulator & DD 1 \\
\hline 7. & Independent Director & Commercial Bank & ID 1 \\
\hline 8 & Independent Director & Commercial Bank & ID 2 \\
\hline 9. & Nominated Director & State owned Commercial Bank & ND \\
\hline 10. & Managing Director & Commercial Bank & MD 1 \\
\hline 9. & Managing Director & Commercial Bank & MD 2 \\
\hline 10. & Managing Director & Commercial Bank & MD 3 \\
\hline 11. & Managing Director & Commercial Bank & MD 4 \\
\hline 12. & Managing Director & Commercial Bank & MD 5 \\
\hline 13. & Chairman & Commercial Bank & $\mathrm{CH} 1$ \\
\hline 14. & Chairman & Commercial Bank & $\mathrm{CH} 2$ \\
\hline 15. & $\begin{array}{l}\text { Former Finance Advisor to the } \\
\text { Caretaker Government }\end{array}$ & Policy Maker/ Civil Society & MAI \\
\hline 16. & $\begin{array}{l}\text { Former Advisor to the Caretaker } \\
\text { Government }\end{array}$ & Policy Maker/Civil Society & AAK \\
\hline 17. & Corporate Governance Analyst & $I F C$ & CGIFC 1 \\
\hline 18. & Corporate Governance Analyst & $I F C$ & CGIFC 2 \\
\hline 19. & Deputy Managing Director & Commercial Bank & DMD 1 \\
\hline 20. & Deputy Managing Director & Commercial Bank & DMD 2 \\
\hline 21. & $\begin{array}{l}\text { State Minister, Ministry of Finance } \\
\text { and Planning }\end{array}$ & State Bodies & $\mathrm{SM}$ \\
\hline
\end{tabular}


Table 2: Ideal types for CSR strategy for banks in Bangladesh (adopted from Thornton, 2004; Arena et al., 2018; Kim and Chung, 2017)

\begin{tabular}{|c|c|c|c|}
\hline Approach & Market & Community & Family \\
\hline $\begin{array}{l}\text { Balancing and } \\
\text { relationships } \\
\text { between CSR } \\
\text { objectives }\end{array}$ & $\begin{array}{l}\text { Profit } \\
\text { maximization and } \\
\text { instrumental } \\
\text { approach }\end{array}$ & $\begin{array}{l}\text { No prioritization- } \\
\text { focus on the } \\
\text { impact on (local) } \\
\text { communities }\end{array}$ & $\begin{array}{l}\text { Maintain family } \\
\text { reputation and } \\
\text { inherit family } \\
\text { tradition }\end{array}$ \\
\hline System boundaries & $\begin{array}{l}\text { set by the } \\
\text { company's } \\
\text { operations and its } \\
\text { reference } \\
\text { market }\end{array}$ & $\begin{array}{l}\text { Geographical } \\
\text { boundaries and/or } \\
\text { common } \\
\text { activities and } \\
\text { beliefs }\end{array}$ & $\begin{array}{l}\text { Significant overlap } \\
\text { between the } \\
\text { family and their } \\
\text { corporations }\end{array}$ \\
\hline $\begin{array}{l}\text { Stakeholders' } \\
\text { engagement }\end{array}$ & $\begin{array}{l}\text { Selected } \\
\text { stakeholders (in } \\
\text { particular the } \\
\text { powerful ones) } \\
\text { with the aim of } \\
\text { furthering } \\
\text { the goals of the } \\
\text { organization }\end{array}$ & $\begin{array}{l}\text { Interested } \\
\text { communities } \\
\text { (without } \\
\text { differentiation } \\
\text { between } \\
\text { legitimate/no } \\
\text { legitimate, } \\
\text { powerful/non- } \\
\text { powerful) } \\
\end{array}$ & $\begin{array}{l}\text { Weak shareholder } \\
\text { rights and } \\
\text { protection }\end{array}$ \\
\hline $\begin{array}{l}\text { Collaborations } \\
\text { and } \\
\text { alliances }\end{array}$ & $\begin{array}{l}\text { Strategically } \\
\text { selected } \\
\text { collaborations and } \\
\text { alliances }\end{array}$ & $\begin{array}{l}\text { Collaborations and } \\
\text { alliances with } \\
\text { actors } \\
\text { involved in the } \\
\text { community }\end{array}$ & Family as firm \\
\hline $\begin{array}{l}\text { Accountability and } \\
\text { reporting }\end{array}$ & $\begin{array}{l}\text { Legitimacy and } \\
\text { reputation } \\
\text { management }\end{array}$ & $\begin{array}{l}\text { Monitoring of } \\
\text { issues that are } \\
\text { relevant to } \\
\text { the community }\end{array}$ & $\begin{array}{l}\text { Unconditional } \\
\text { loyalty }\end{array}$ \\
\hline
\end{tabular}


Table 3: Commercial banks' approach towards CSR

\begin{tabular}{|l|l|l|l|l|}
\hline \multicolumn{1}{|c|}{ Approach } & \multicolumn{1}{|c|}{ Bangladesh Bank } & \multicolumn{3}{c|}{ Commercial banks } \\
\cline { 2 - 5 } & \multicolumn{1}{|c|}{ Community logic } & \multicolumn{1}{c|}{ Market logic } & \multicolumn{1}{c|}{ Family logic } & \multicolumn{1}{c|}{ Community logic } \\
\hline $\begin{array}{l}\text { Balancing and } \\
\text { relationships } \\
\text { between CSR objectives }\end{array}$ & $\begin{array}{l}\text { Acknowledgement of } \\
\text { support of the common } \\
\text { people }\end{array}$ & $\begin{array}{l}\text { Maximization of the } \\
\text { company's profit through } \\
\text { demonstrating allegiance } \\
\text { with political leadership, } \\
\text { or personal (for example, } \\
\text { political) benefits of the } \\
\text { directors }\end{array}$ & $\begin{array}{l}\text { Maintain/enhance } \\
\text { reputation of the family } \\
\text { and political leadership }\end{array}$ & $\begin{array}{l}\text { Focus on community } \\
\text { development }\end{array}$ \\
\hline $\begin{array}{l}\text { Stakeholders } \\
\text { engagement }\end{array}$ & $\begin{array}{l}\text { Banks should do } \\
\text { something for the society }\end{array}$ & $\begin{array}{l}\text { Prioritization of powerful } \\
\text { group of stakeholders } \\
\text { (ruling political regime) }\end{array}$ & $\begin{array}{l}\text { Only with political } \\
\text { leadership }\end{array}$ & Community engagement \\
\hline $\begin{array}{l}\text { Collaborations and } \\
\text { alliances }\end{array}$ & $\begin{array}{l}\text { Collaborations through } \\
\text { corporations outside the } \\
\text { banking industry }\end{array}$ & $\begin{array}{l}\text { BAB to exert influence on } \\
\text { government policies }\end{array}$ & $\begin{array}{l}\text { Collaborations with } \\
\text { political parties by helping } \\
\text { them attain the leader's } \\
\text { vision }\end{array}$ & $\begin{array}{l}\text { Collaborations across } \\
\text { different activities, such as } \\
\text { education, health }\end{array}$ \\
\hline $\begin{array}{l}\text { Accountability and } \\
\text { reporting }\end{array}$ & $\begin{array}{l}\text { Publication of annual } \\
\text { report on CSR initiatives }\end{array}$ & $\begin{array}{l}\text { CSR reporting aimed at } \\
\text { demonstrating proximity } \\
\text { to political leadership }\end{array}$ & $\begin{array}{l}\text { CSR activities and } \\
\text { reporting aimed at } \\
\text { demonstrating loyalty }\end{array}$ & $\begin{array}{l}\text { Production of } \\
\text { sustainability reports to } \\
\text { demonstrate social } \\
\text { accountability }\end{array}$ \\
\hline
\end{tabular}

